\title{
The Effects of Health Aid on Heterogeneous Child Health Outcomes: An Empirical Evidence from Nigeria
}

\author{
Olufunmilayo Olayemi Jemiluyi ${ }^{1}$, Rebecca Folake Bank-Ola² , Ifeoluwa Alao-Owunna \\ ${ }^{1}$ Department of Economics, Adeleke University, Ede, Nigeria. \\ jemiluyi.olayemi@adelekeuniversity.edu.ng ORCID iD: https://orcid.org/0000-0002-9635-4019 \\ ${ }^{2}$ Department of Economics, Adeleke University, Ede, Nigeria, \\ rebecca.bank-ola@adelekeuniversity.edu.ng ORCID iD: https://orcid.org/0000-0002-7370-9403 \\ ${ }^{3}$ Department of Economics, Adeleke University, Ede, Nigeria, \\ ifeoluwa.alao-owunna@adelekeuniversity.edu.ng ORCID iD: https://orcid.org/0000-0002-4643-220X
}

\begin{tabular}{|c|c|}
\hline Article Info & \multirow{9}{*}{$\begin{array}{l}\text { Abstract } \\
\text { Purpose: This study investigates the effectiveness of health-aid in Nigeria, } \\
\text { with focus on child health outcomes. In particular, the study aims to examine } \\
\text { whether health aid has yielded significant gains in child health in Nigeria. } \\
\text { Methodology/Approach/Design: Secondary data on neonatal, infant and } \\
\text { under } 5 \text { mortality as well as measles and DPT immunization were used. The } \\
\text { stationarity of the variables was ascertained using the augmented Dickey- } \\
\text { Fuller and Philip-Perron unit root tests. In order to confirm the presence or } \\
\text { otherwise of long-run relationship among the selected variables, Johansen } \\
\text { cointegration test was carried out and the obtained coefficients and p-values } \\
\text { indicate evidences of long-run relationship. Finally, the study used the fully } \\
\text { modified ordinary least square (FMOLS) estimator to examine the effects of } \\
\text { aid targeted at children health on the various child health outcomes. }\end{array}$} \\
\hline Article history: & \\
\hline November 2020 & \\
\hline $\begin{array}{l}\text { Revised: } 09 \text { February } 2021 \\
\text { Accepted: } 11 \text { February } 2021\end{array}$ & \\
\hline Keywords: & \\
\hline Healtl & \\
\hline & \\
\hline & \\
\hline Nigeria & \\
\hline JEL: H5 H51, O15, P46 & $\begin{array}{l}\text { Results: The results suggest the existence of long-run relationships between } \\
\text { health aid and child health indicators, with aid having reducing impacts on }\end{array}$ \\
\hline Paper Type : & the mortality indicators and a positive correlation with child immunization \\
\hline Research Article & $\begin{array}{l}\text { coverage. Also, public health expenditure, literacy rate and urbanization rate } \\
\text { are negatively correlated with measures of children mortality and positively }\end{array}$ \\
\hline Corresponding Author: & $\begin{array}{l}\text { correlated with the measures of immunization coverage. Except for infant } \\
\text { mortality, economic growth proxy by GDP growth rate has insignificant effect } \\
\text { on child health. }\end{array}$ \\
\hline $\begin{array}{l}\text { Olufunmilayo Olayemi } \\
\text { Jemiluyi }\end{array}$ & $\begin{array}{l}\text { Practical Implications: Sustained improvement in children health is the core } \\
\text { objective of aids aimed at children's health, and findings of this research will }\end{array}$ \\
\hline Email: & $\begin{array}{l}\text { serve as a framework for health policymakers in understanding the } \\
\text { contributions of health aid inflow to specific indicators of child health in }\end{array}$ \\
\hline jemil & \\
\hline & $\begin{array}{l}\text { Originality/Value: This study makes a number of contributions to the ongoing } \\
\text { discussion on the effectiveness of health-specific ODA in Nigeria. Despite the } \\
\text { inconclusiveness of the health aid-health outcomes literature, this study has } \\
\text { shown that children health aid has led to improvement in children health in } \\
\text { Nigeria. While previous studies have focused on child mortality indicators, } \\
\text { this study examined the effect on various measures of children health } \\
\text { including children immunization coverage. }\end{array}$ \\
\hline
\end{tabular}

\section{Introduction}

Improved health status has continued to enjoy wide support among both policymakers and academics. Hence the discussion on the issue of health funding has remained relevant in both empirical and theoretical literature. The extra ordinary growth in DAH is not unconnected to the 
increasing attention to the precarious health conditions in the developing regions evidenced in the health focal points of the Millennium Development Goals and the post-2015 Sustainable Development Goals (SDGs).

In recent time, the global health sector has witnessed diverse forms of dramatic changes ranging from increasing prevalence of communicable and non-communicable diseases, emergence of new and re-emerging infectious diseases ${ }^{1}$, increasing number of multilateral agencies and health donor partners ${ }^{2}$, extra ordinary growth in financial commitment in terms of health funding ${ }^{3}$, and overall significant increase in the recognition of the role of health in achieving sustainable development ${ }^{4}$. In particular the issue of health financing has received a great deal of attention in the past decades with intense focus on development assistance for health (DAH) (IHME, 2019). According to IHME statistics (2016), health aid witnessed a surge in the decade 2000 -2010 having an average annual growth rate of $11.4 \%$. Although the rate of growth has declined considerably since 2010, it peaked at US\$38 billion in 2013 and fell to US\$36.4 billion in 2015. In spite of the global remarkable progress in tackling health challenges and the substantial increase in the flow of health donor funding to the poor regions, health outcomes in most developing countries of the world have continued to lag behind. Health capital in developing economies is characterized by low life expectancy, poor maternal and child health and high morbidity and mortality rates (World Development Indicators (WDI), 2019). This, in no measure, has cast doubt on the effectiveness of health aid in the poor regions, thus birthing an invigorating research on the nexus between DAH and health outcomes in those regions.

In Nigeria, controversy also abounds as to the effectiveness of DAH in mitigating the diverse arrays of health challenges plaguing the country. While there has been a substantial hike in official development assistance (ODA) $)^{5}$ and in particular those targeted towards health ${ }^{6}$, health outcomes in Nigeria compare poorly with those of other developing countries. In 2016, Nigeria accounted for about $18 \%$ of the sub-Saharan Africa population, with $1.5 \%$ of national prevalence rate of HIV/AIDS and $4 \%$ of the global burden of tuberculosis, while health expenditure in the same period was only $3.7 \%$ of GDP. In 2018, Nigeria ranked 19 in GDP per capita in the Africa continent having life expectancy of 53.9 years and adult mortality rate of 347.9/1,000 adults. Moreover, Nigeria bears a significant burden of global infant and maternal mortality, accounting for $14 \%$ of global maternal mortality rates. The founder and chairman of the Bill and Melinda

\footnotetext{
${ }^{1}$ The world has continued to be plagued with new and re-emerging infectious, with the most recent being the Ebola virus, SARS, Lassa fever and the deadly Corona virus

${ }^{2}$ Such as the Bill and Melinda Gates Foundation, GAVI Alliance, the Global Fund to Fight AIDS, Tuberculosis and Malaria, the President's Emergency Plan for AIDS Relief (PEPFAR) and other non-governmental organizations (NGO) and private philanthropies

${ }^{3}$.For example, as of December 2018, three health Development Impact Bonds (DIBs) including the Utkrisht Impact Bond, the Cameroon Cataract Bond and the Humanitarian Impact Bond have been launched with US\$38.1 million in outcome funding, about US\$27 million in upfront investment and impact target of at least 31,600 people (Clarke et al. 2018)

${ }^{4}$ Evidenced in health focal points of global development programs such as the Millennium Development Goals (MDGs) and the Sustainable Development Goals (SDGs) as well as increasing wave of both theoretical and empirical research in health.

${ }^{5}$ Hereafter, official aid, official development assistance and its acronym ODA shall be used interchangeably throughout this study.

${ }^{6}$ Hereafter, health-specific aid, development assistance for health and its acronym DAH shall be used interchangeably throughout this study.
} 
Gates Foundation in a recent address of the Nigeria's National Economic Council (NEC), remarked that Nigeria is one of the most dangerous places to give birth in the world. Based on available data, infant, neonatal and under-five mortality stood at 75.7, 36 and 119.9 per 1,000 live births respectively (WDI, 2018).

The prevailing poor living condition and daunting health challenges in Nigeria have continued to raise questions on the role of official development assistance in improving living condition as well as health outcomes in Nigeria both in the academics and political fronts. However, a large number of the debate in the academic circle has focused on the economic growth-and poverty reduction-effects of $\mathrm{ODA}^{7}$, while there is paucity of analyses on the effectiveness of ODA on health outcomes. The few extant studies which investigate the association between official development assistance and health performance in Nigeria considered aggregate official development assistance, thereby losing sector-specific information. Also, examination of the effect of official development assistance on child health indicators in Nigeria is scarce in the literature, with the available tiny evidence focusing on infant mortality.

Although, there exist a few panel analyses of the association between DAH and health outcomes on sub-Saharan Africa region, a great deal of heterogeneity is masked by such analyses, thus leading to spurious estimation. Hence, this study makes a number of contributions to the ongoing discussion on the effectiveness of health-specific ODA in Nigeria. First, following studies such as Furuoka et al. (2019), Pickbourn and Ndikumana (2018) and Winkleman and Adams (2017), we investigate the effect of development assistance on health (DAH)on child health outcomes in Nigeria. A common limitation of the existing studies is the aggregation of different types of development aid, thereby making it impossible to infer on the contribution of sector-specific aid (Joseph et al., 2017; Okon, 2012). Aid disbursement is often sector-based; hence an aggregated analysis of aids effectiveness can be misleading. Therefore, a sector-specific analysis of the effect of official development assistance is likely to yield more robust conclusions thereby allowing aid donors and policy makers to identify the most effective among aids.

Second, this study is one of the few that investigate the effect of outcome-specific DAH by studying the effect of official development assistance from the United Nations International Children Fund (UNICEF) ${ }^{8}$ on child health outcomes. An analysis involving outcome-specific DAH has the advantage of providing a more detailed analysis of the statistical relationships existing between foreign aid and health (Furuoka et al., 2019; Doucouliagos et al., 2019).Finally, rather than the usual focus on conventional outcomes such as infant mortality and under-five mortality, we adopt heterogenous novel child health outcomes including neonatal mortality and measles and diphtheria, pertussis (or whooping cough), and tetanus (DPT) immunization.

\footnotetext{
${ }^{7}$ See Agunbiade and Mohammed (2018), Fashinaet al. (2018), Ugochukwu et al. (2016)

8 The United Nations Children's Fund is the United Nations agency saddled with the responsibility of providing developmental aid to children worldwide
} 


\section{Literature Review}

Although the literature on aid effectiveness is replete with mixed findings, over the years, critical conclusions have emerged from the different strands of the literature. In general, a large chunk of the available evidence focuses on the role of ODA in enhancing the growth trajectories of the recipient countries and in ameliorating poverty particularly in the poor low-income countries which are significant beneficiaries of aid. The large body of cross-country and country-specific analyses investigating the effects of ODA on economic growth and poverty has birthed diversified conclusions. For example, while studies such as Harb and Hall (2019), Mahembe and Odhiambo (2019, 2017), Tahir et al. (2019), Aghoutane and Karim (2017), Daalgard and Hansen (2017), Charles (2016), Jones and Tarp (2016), Gyimah-Brempong, Racine and Gyapong (2012) and Burnside and Dollar (2000), find that foreign aid promotes economic growth and ameliorate poverty, Wako (2017), Moyo and Mafuso (2017), Feeny and De Silva (2012), Rajan and Subramanian (2011), Djankov et al. (2008) deliberated that aid has impeded economic growth and worsened poverty in the developing regions.

Moreover, a sizeable number of studies investigating the growth- and development-impact of ODA have contended that certain socio-economic and political conditions are imperative for aids to be effective. In that regard, aid is found to be effective in recipient countries with quality institutions (Maruta et al., 2020; Kathavate \& Mallik, 2012); sound governance (Daalgard et al., 2004); democracy (Kosack, 2003). In contrast to the above viewpoint, others such as Hansen and Tarp, (2000) have argued that even in the presence of these conditions, aid may still hamper economic growth and increase poverty level

Another offshoot of the aid effectiveness literature studies is about the effect of aid on nongrowth outcomes including human capital development (Fashina et al. 2018; Apple 2012; Azarnet, 2008), agriculture (Dhahri \& Omri, 2020; Ssozi et al., 2019; Alabi, 2014; Kaya et al., 2013), infrastructure (Ndikumana \& Pickbourn, 2017) and health (Afridi \&Ventelou, 2013). Specifically, empirical investigations of the impact of aid on health outcomes can be couched into two broad macro categories; those that examine how aggregate official development assistance (ODA) affects aggregate health outcomes and those that focus on the impacts of health-specific aid (DAH) on aggregate health outcomes. There also exist a few micro and macro analyses which investigate the effect of health aid to a specific health program or disease on outcomes in that particular program or disease. For the two major strands, the extant literature lacks consensus on how aggregate ODA or DAH affect aggregate health outcomes.

For the strand that investigate the association between ODA and aggregate health outcomes, studies such as Winkleman and Adams (2017), Taylor et al. (2013), Chauvet et al. (2013) document that foreign aid spurs improvement in aggregate health outcomes. For example, Winkleman et al. (2017) stratifying the dataset into four groups of low, medium, high and very high developed countries based on the UN Human Development Index (UN-HDI) concludes that while foreign aid is inversely related to child mortality in the study's full sample, the effect is the strongest in the medium developed countries. On the contrary, negative or no significant impact

Copyright (C) 2021, Journal of Advanced Research in Economics and Administrative Sciences (JAREAS), Under a Creative Commons Attribution 4.0 International License 
of foreign aid on health outcome is substantiated in Thomson et al. (2017), Pandolfelli et al. (2014), Wilson (2011), Mishra and Newhouse (2009), Williamson (2008). Analyzing the impact of the financial aid provided by the IMF as well as its market-oriented policy prescriptions on health outcomes, Thomson et al. (2017) and Pandolfelli et al. (2014) argue that aid has a deleterious impact on child and maternal health in aid-receiving countries.

A review of the strand which assesses the influence of health-specific aid (DAH) on aggregate health outcome similarly reveals the existence of a sizeable body of evidences with a nearconsensus of pro-health effect of DAH. For instance, Doucouliagos et al. (2019) find that DAH reduces infant mortality based on data from 96 aid recipient countries. Similar findings are corroborated in Pickbourn and Ndikumana (2019) for sub-Saharan Africa, Banchani and Swiss (2019) for a sample of 130 low-and middle-income countries, Yogo and Mallaye (2015) for 34 SSA countries and Bendavid and Bhattarchaya (2014) for 140 aid recipient countries. Pickbourn et al. (2019) in particular find that development assistance for aid is related to reduction in diarrhea related death in under-5 children. And the findings of Bachani and Swiss (2019) shows that while total foreign aid has a limited effect on maternal mortality reduction, aids targeted at reproductive health is associated with substantial decline in maternal mortality. In the same vein, Bendavid et al. (2014) upholds the pro-health effect of health-specific aid, with improvement in life expectancy and under-5 mortality being associated with aid receipt.

As regards the strand that centres on the effects of DAH targeted at specific health program or disease on outcomes in that particular program or disease, there seems to be a near-consensus that health aid allocated to specific programs improves health outcomes in the targeted areas. For example, in a study on the effectiveness of HIV-specific fund in Malawi and Ethiopia, Rasschaert et al. (2011) find that increased funding for HIV-related health programs is associated with scale up of antiretroviral treatment (ART) in both countries. This finding is earlier corroborated by Shiffman et al. (2009) for the same scope. Similarly, Bendavid and Bhattacharya (2009) conclude that health aid targeted at malaria significantly reduced under-5 mortality among poor households in 49 aid recipient countries in Africa, Asia, South America and the Caribbean. In another macro study of 120 low- and middle-income countries, Hsiao and Emdin (2015) find that foreign aid targeted to HIV/AIDS, malaria and tuberculosis is correlated with decline in HIV and malaria death respectively while no significant association is observed between TB specific-aid and reduction in TB death. A similar trend of result is documented for a panel of developing countries in an earlier study by Burguet and Soto (2012). Testing the impact of infectious disease-specific aids (IDA) on under-5 mortality, the research output affirms that IDA causes a significant reduction in under-5 mortality due to infectious diseases. Focusing on the MDG 5, Taylor et al. (2013) find that the improvement in maternal and reproductive health outcomes is associated with program-specific aid interventions.

\section{Methodology and Procedures}

\section{Technique of Analysis}

Copyright (C) 2021, Journal of Advanced Research in Economics and Administrative Sciences (JAREAS), Under a Creative Commons Attribution 4.0 International License 
For the evaluation of the impact of health-specific DAH on child health outcomes in Nigeria, this study adopts the time series data analysis. Hence, to estimate the long-run coefficients of the time series model, the fully modified ordinary least square method (hereafter FMOLS) is employed. The FMOLS has been adjudged more efficient to the ordinary least square (hereafter OLS). When applied to cointegrating series, the OLS estimates may suffer from serial correlation and heteroscedasticity, thereby producing inconsistent and biased estimates. The FMOLS technique of analysis was developed by Philip and Hansen (1990) to correct the deficiencies associated with OLS estimator by modifying the least squares to account for serial correlation effects and endogeneity arising from cointegration among variables of interest. According to Philips (1993), FMOLS has an important intent of providing a framework for the estimation of time series by taking the advantage of non-stationarity of the series and potential cointegrating relationships among the series of interest without preliminary testing or explicitly stating the model form. Based on the initial work of Philip and Hansen (1990), the FMOLS method estimator was initially developed to estimate cointegrating relationship having a combination of I(1) regressors. However, the estimator framework was extended in Philips and Solo (1992) to permit the evaluation of the asymptotic behavior of the FMOLS method in models with full rank $\mathrm{I}(1)$ regressors as well as those having combinations of $\mathrm{I}(1)$ and $\mathrm{I}(0)$ regressors.

In all, the FMOLS estimator has been found useful for robust estimation of both time series and panel data analyses, producing asymptotically unbiased and normally distributed estimated coefficients (Philips and Hansen, 1990; Philips and Solo, 1992; Pedroni, 2000; Kao and Chiang, 2000). Moreover, aside mitigating the challenge associated with correlation among series and problem of endogeneity, FMOLS has been found to be efficient in small sample size (Ramirez, 2007).

\section{Data}

Annual time series from 1970 to 2018 were employed for the analyses. All data were sourced from the 2019 edition of the World Development Indicators (WDI) database of the World Bank. While the study seeks to explore the relationship between DAH and child health indicators, other macroeconomic variables which have been identified as determinants of child health were included as control variables in order to avoid misspecification error. For example, a strong correlation has been established between level of income and health outcomes (Salahuddin et al., 2019, O’Hare et al., 2013). Thus, per capita gross domestic product is included in the analysis to assess the impact of income on child health outcomes in Nigeria. Evidence of strong correlation between child health and other macroeconomic variables such as literacy rate, degree of urbanization and public health spending also abound in the literature. Educated parents or guardians tend to be knowledgeable in caring for children while increased public health funding makes resources available for health care. In the same vein, a heated debate exists as to the role of increasing rate of urbanization in population health. While some studies argue that increasing urbanization is deleterious to health, others opine that urbanization promote health through access to better health infrastructure in urban centres. Hence, literacy rate measured by gross

Copyright (C) 2021, Journal of Advanced Research in Economics and Administrative Sciences (JAREAS), Under a Creative Commons Attribution 4.0 International License 
primary school enrolment, urbanization rate and public health spending are incorporated in the model. Development assistance for health (Dah) is the key variable of interest proxy by official development assistance by UNICEF.

The definitions of the variables employed in this study, as well as the adopted codes and unit of measurements are presented in Table 1.

Table 1: Definitions of the adopted variables

\begin{tabular}{|l|l|l|}
\hline Variables & Definitions & Units of measurement \\
\hline DAH & Net official flow from UN agencies (UNICEF) & US\$ \\
\hline NEO & Neonatal mortality rate (per1,000 live births) & Per 1,000 live births \\
\hline INF & Infant mortality rate & Per 1,000 live births \\
\hline UND5 & Under-5 mortality rate (per 1,000 live births) & Per 1,000 live births \\
\hline GDPG & GDP growth rate & Percent \\
\hline SCHP & Primary school enrolment & Percent \\
\hline URB & Urbanization rate & Percent \\
\hline MEA & Measles immunization & Percent \\
\hline DPT & Diphtheria, pertussis and tetanus (DPT) immunization & Percent \\
\hline
\end{tabular}

Source: Author's computation based on data from World Development Indicators (2019)

\section{Model specification}

The following linear model is estimated to uncover the long-run relationship between DAH and the selected child health indicators.

$$
\text { Chd }=\mathrm{f}(\mathrm{DAH}, \mathrm{Gdpc}, \mathrm{Gexp}, \text { Schs, Urb) (1) }
$$

where chd is a vector of various indicators of child health including infant mortality rate, neonatalmortality rate, under-5 mortality rate, DPT and measles immunization. Dah, Gdpg, Gexp, Schp and Urb represent development assistance for health, GDP growth rate, government expenditure, school enrolment rate and urbanization rate respectively.

Following from equation (1), the following equations are estimated

Model 1

$$
\operatorname{Infm}=\propto_{0}+\propto_{1} \text { Dah }+\propto_{2} \text { Gdpg }+\propto_{3} \text { Gexp }+\propto_{4} \text { Schp }+\propto_{5} \text { Urb }
$$

Model 2

$$
\text { Neom }=\beta_{0}+\beta_{1} \text { Dah }+\beta_{2} \text { Gdpg }+\beta_{3} \text { Gexp }+\beta_{4} \operatorname{Schp}+\beta_{5} \text { Urb }
$$

Model 3

$$
\operatorname{Und} 5=\partial_{0}+\partial_{1} \mathrm{Dah}+\partial_{2} \mathrm{Gdpg}+\partial_{3} \mathrm{Gexp}+\partial_{4} \mathrm{Schp}+\partial_{5} \mathrm{Urb}
$$


Model 4

$\mathrm{DPT}=\pi_{0}+\pi_{1} \mathrm{Dah}+\pi_{2} \mathrm{Gdpg}+\pi_{3} \mathrm{Gexp}+\pi_{4} \mathrm{Schp}+\pi_{5} \mathrm{Urb}$

Model 5

Meal $=\vartheta_{0}+\vartheta_{1}$ Dah $+\vartheta_{2}$ Gdpg $+\vartheta_{3}$ Gexp $+\vartheta_{4} \operatorname{Schp}+\vartheta_{5}$ Urb

\section{Results and Discussion}

This section focuses on the presentation of the econometric results as well as the interpretation discussion of the findings.

\section{Descriptive Statistics}

Based on the descriptive statistics reported in Table 2, all the variables show high level of consistency as the mean and median values of each variable are within the reported minimum and maximum values. Except for the school enrolment (Schp), GDP growth rate (Gdpg) and the immunization series which have high standard deviation ranging between 5.54 and 12.78, all other data have low standard deviation values (ranging between 0.09 and 0.83 ), while those with high values are widely spread around indicating that the individual data for those series are clustered around the mean value for each series. In all, the series for the degree of urbanization has the least deviation from the mean with a standard deviation of 0.08 while the highest degree of dispersion is exhibited by the DPT immunization series.

Table 2: Summary statistics of the variables

\begin{tabular}{|l|l|l|l|l|l|l|l|l|l|}
\hline Variables & Dah & Inf & Neo & Und5 & Measles & DPT & GDPg & Schp & Urb \\
\hline Mean & 16.76 & 4.65 & 3.80 & 5.15 & 42.94 & 38.2 & 3.18 & 94.13 & 2.58 \\
\hline Median & 16.75 & 4.72 & 3.87 & 5.23 & 42.0 & 39.0 & 4.21 & 93.49 & 2.58 \\
\hline Maximum & 17.88 & 4.83 & 3.96 & 5.35 & 65.0 & 63.0 & 15.33 & 113.08 & 2.71 \\
\hline Minimum & 14.99 & 4.33 & 3.58 & 4.79 & 9.0 & 9.0 & 13.13 & 78.66 & 2.49 \\
\hline Std. Dev. & 0.83 & 0.19 & 0.13 & 0.21 & 12.79 & 12.89 & 5.54 & 8.81 & 0.07 \\
\hline Skewness & -0.32 & -0.46 & -0.44 & -0.47 & -0.19 & -0.06 & -0.87 & 2.57 & 0.09 \\
\hline Kurtosis & 2.22 & 1.56 & 1.50 & 1.57 & 3.36 & 2.43 & 4.53 & 2.69 & 1.71 \\
\hline
\end{tabular}

Source: Author's computation (extracted from E-views-9)

For the inference on the normality assumption, the measure of asymmetry of the probability distribution of each series around its mean indicated by the skewness statistics show that all the series are asymmetric and not normally distributed as all the series are negatively skewed (leftward)

Furthermore, the degree of peakedness of the series' distribution evidenced in the kurtosis values provides varying information about the distribution of the series of interest. For a normally distributed series, the coefficient of the kurtosis is expected to be 3.0, and such a distribution is

Copyright (C) 2021, Journal of Advanced Research in Economics and Administrative Sciences (JAREAS), Under a Creative Commons Attribution 4.0 International License 
said to be mesokurtic. It is a relatively high peak distribution (leptokurtic) if the kurtosis value is higher than 3 and a relatively high flat-topped distribution (platykurtic) when the kurtosis value is lesser than 3. Thus, the reported kurtosis values for the adopted series indicate that aside GDP growth and measles immunization which are leptokurtic, every other series is platykurtic. This corroborates the skewness statistics which indicate that none of the series is normally distributed.

\section{Unit Root Test}

Most series of economic variables exhibit trending behaviour in the mean i.e. they have nonstationarity property. Employing such series in econometric analyses tend to produce spurious estimates. Hence, in order to determine the existence or otherwise of long run relationships among the variables of choice, we test for the stationarity of the series of the variables using some of the tests offered in the statistical theory. Specifically, the Augmented Dickey-Fuller (ADF) and Philip-Perron (PP) tests are used

Table 3: Results of the augmented Dickey-Fuller and Philip-Perron unit root test

\begin{tabular}{|l|l|l|l|l|}
\hline Variables & \multicolumn{3}{|l|}{ Augmented Dickey-Fuller (ADF) } & \multicolumn{2}{l|}{ Philip-Perron (PP) } \\
\hline & Level & $\boldsymbol{1}^{\text {st }}$ Difference & Level & $\boldsymbol{1}^{\text {st }}$ Difference \\
\hline Inf & 1.2950 & $3.9011^{*}$ & 1.8789 & 1.1181 \\
\hline Neo & 1.6011 & $4.1013^{*}$ & 0.3891 & 0.5611 \\
\hline Und5 & 1.5858 & $3.5192^{*}$ & 1.3122 & 1.1148 \\
\hline Measles & 2.3502 & $6.0106^{*}$ & 2.3932 & $6.0187^{*}$ \\
\hline DPT & 2.305 & $6.0106^{*}$ & 2.4149 & $6.0395^{*}$ \\
\hline DAH & 1.6723 & $5.2190^{*}$ & 1.8849 & $6.8926^{*}$ \\
\hline Gdpg & $4.1062^{*}$ & $9.9317^{*}$ & $4.1204^{*}$ & $10.2501^{*}$ \\
\hline Gexp & 2.0419 & $5.4382^{*}$ & 2.0517 & $8.6086^{*}$ \\
\hline Schp & 2.7124 & $3.5603^{* *}$ & 1.5052 & $3.6521^{*}$ \\
\hline Urb & $5.4523^{*}$ & $3.0394^{* *}$ & 2.3488 & $4.3529^{*}$ \\
\hline
\end{tabular}

Note: $*$ and $* *$ indicate statistical significance at 1 and 5 percent respectively.

Source: Authors' computation (extracted from E-views-9)

The results presented in Table 3 show that, using both tests, all the variables are non-stationary at levels except GDP growth rate and degree of urbanization (Gdpg and Urb). However, at first difference, except for gross primary school enrolment and degree of urbanization which are only stationary at $5 \%$ level of significance, all other series are stationary at $1 \%$ level of significance for the ADF test. On the other hand, for the PP test, the null hypothesis of presence of unit root could not be rejected even at first difference for all the mortality series (infant (Inf), neonatal (Neo) and under5 (Und5). Thus, following the establishment of stationarity in the selected data, we proceed to test for the existence or otherwise of long-run relationship among the variables using the Johansen cointegration test.

Copyright (C) 2021, Journal of Advanced Research in Economics and Administrative Sciences (JAREAS), Under a 


\section{Johansen Cointegration Test}

For the purpose of examination of the existence of long-run relationship among the variables in Nigeria, we adopt the Johansen cointegration test which uses the results of the trace statistics and maximum eigenvalues to test for the cointegration ranks among series. In particular, we conduct separate test for each model of the child outcome indicators. The results are shown in Table 4.All the estimated cointegrating models show evidence of long-run relationships with the infant, neonatal and under 5 mortality models indicating three cointegrating equations each while the measles and DPT models indicate two and one cointegrating equations respectively.

\section{Fully Modified Ordinary Least Square (FMOLS) Estimator}

The results of the FMOLS regression are displayed in Table 5. The results show the coefficients, direction and significance of the effects of the independent variables on child health in Nigeria.

The results of the evaluation of effect of foreign aid on health on child outcomes are presented in Table 5. In order to avoid autocorrelation, the adopted child health outcomes are alternated in the estimated model and the results are presented in column two to six of Table 5. In all the estimated models, DAH is significantly associated with child health outcomes while the signs and magnitudes of the association vary among the adopted child health outcomes.

Table 4: Results of Johansen Cointegration Test

\begin{tabular}{|c|c|c|c|c|}
\hline Model & $\begin{array}{l}\text { Hypothesized } \\
\text { No of CE(s) }\end{array}$ & Eigenvalue & Trace statistics & Prob value \\
\hline \multirow{6}{*}{ Infant mortality } & None & 0.9023 & 166.8928 & 0.0000 \\
\hline & At most 1 & 0.8322 & 101.8189 & 0.0000 \\
\hline & At most 2 & 0.5738 & 51.7506 & 0.0206 \\
\hline & At most 3 & 0.4832 & 27.8745 & 0.0820 \\
\hline & At most 4 & 0.2350 & 9.3896 & 0.3306 \\
\hline & At most 5 & 0.0653 & 1.8995 & 0.1693 \\
\hline \multirow{6}{*}{ Und5 mortality } & None & 0.9336 & 187.5171 & 0.0000 \\
\hline & At most 1 & 0.8852 & 111.5880 & 0.0000 \\
\hline & At most 2 & 0.5795 & 50.9707 & 0.0248 \\
\hline & At most 3 & 0.4721 & 26.7116 & 0.1089 \\
\hline & At most 4 & 0.2193 & 8.8243 & 0.3819 \\
\hline & At most 5 & 0.0653 & 1.8909 & 0.1691 \\
\hline \multirow{5}{*}{$\begin{array}{l}\text { Neonatal } \\
\text { mortality }\end{array}$} & None & 0.9054 & 150.4522 & 0.0000 \\
\hline & At most 1 & 0.6614 & 84.4143 & 0.0022 \\
\hline & At most 2 & 0.6274 & 54.0935 & 0.0116 \\
\hline & At most 3 & 0.4725 & 26.4502 & 0.1158 \\
\hline & At most 4 & 0.2622 & 8.5423 & 0.4094 \\
\hline
\end{tabular}




\begin{tabular}{|c|c|c|c|c|}
\hline & At most 5 & 0.0010 & 0.0281 & 0.8669 \\
\hline \multirow{6}{*}{$\begin{array}{l}\text { Measles } \\
\text { immunization }\end{array}$} & None & 0.9809 & 113.2423 & 0.0018 \\
\hline & At most 1 & 0.8987 & 69.8447 & 0.0498 \\
\hline & At most 2 & 0.8199 & 35.7244 & 0.4104 \\
\hline & At most 3 & 0.7078 & 16.3014 & 0.6909 \\
\hline & At most 4 & 0.2334 & 5.8873 & 0.7088 \\
\hline & At most 5 & 0.0041 & 0.0643 & 0.7999 \\
\hline \multirow{6}{*}{$\begin{array}{l}\text { (DPT) } \\
\text { immunization }\end{array}$} & None & 0.8670 & 119.7750 & 0.0004 \\
\hline & At most 1 & 0.7327 & 69.3432 & 0.0545 \\
\hline & At most 2 & 0.5109 & 36.3599 & 0.3784 \\
\hline & At most 3 & 0.3540 & 18.4826 & 0.5306 \\
\hline & At most 4 & 0.2574 & 7.5576 & 0.5138 \\
\hline & At most 5 & 0.0045 & 0.1193 & 0.7298 \\
\hline
\end{tabular}

Source: Authors' computation (extracted from E-views-9)

For model I, the result suggests that DAH is associated with reduction in infant mortality. A dollar increase in DAH by UNICEF reduces infant mortality by $0.12 / 1,000$ live birth. The observed reducing effect of DAH on infant mortality is in line with the findings of Doucouliagos et al. (2019) and Pickbourn and Ndikumana et al (2018) both of which document similar results between DAH and infant mortality for a panel of 96 aid recipient countries and a sample of SSA countries respectively. Also, this corroborates the UNICEF stance that some levels of progress have been achieved Nigeria in curtailing infant death, although there is still much ground to cover. In fact, in spite of the current high burden of infant mortality in Nigeria, it has declined by about 26\% since 2003 (UNICEF, 2018). Moreover, the observed progress might not be unconnected to financial assistance provided by UNICEF in pursuance of tangible improvements in child health outcomes in Nigeria. Hence, the result might be an indication that DAH provided by UNICEF is channelled toward the development of child health programs thereby culminating in improvement in child health evidenced in reduction in infant mortality.

Table 5: Summary of the FMOLS regressions

\begin{tabular}{|l|l|l|l|l|l|}
\hline Variables & $\begin{array}{l}\text { Model 1 } \\
(\text { Inf })\end{array}$ & $\begin{array}{l}\text { Model II } \\
(\mathrm{Neo})\end{array}$ & $\begin{array}{l}\text { Model III } \\
(\text { Und5) }\end{array}$ & $\begin{array}{l}\text { Model IV } \\
\text { (Measles) }\end{array}$ & $\begin{array}{l}\text { Model V } \\
\text { (DPT) }\end{array}$ \\
\hline $\begin{array}{l}\text { Development assistance for } \\
\text { health (Dah) }\end{array}$ & $-0.1233^{*}$ & $-0.0816^{*}$ & $-0.1381^{*}$ & $0.1140^{*}$ & $0.1391^{*}$ \\
\hline GDP growth rate (GDPg) & $-0.0044^{* *}$ & -0.0013 & $-0.0050^{* *}$ & -0.0011 & 0.0015 \\
\hline $\begin{array}{l}\text { Public health expenditure } \\
\text { (Gexp) }\end{array}$ & $-0.0045^{*}$ & $-0.0029^{*}$ & $-0.0050^{*}$ & $-0.0038^{*}$ & $-0.0037^{*}$ \\
\hline Literacy level (Schp) & $0.0066^{*}$ & $-0.0044^{*}$ & $-0.0073^{*}$ & $-0.0089^{*}$ & $-0.0057^{*}$ \\
\hline Degree of urbanization (Urb) & $-0.8629^{*}$ & $-0.7125^{*}$ & $-0.9812^{*}$ & $0.1267^{*}$ & - \\
\hline
\end{tabular}




\begin{tabular}{|l|l|l|l|l|l|}
\hline & & & & & $0.3703^{* * *}$ \\
\hline Adjusted R & & & & & 0.7607 \\
\hline
\end{tabular}

Note:*,** and $* * *$ indicate statistical significance at 1,5 and 10 percent respectively.

Source: Authors' computation (extracted from E-views-9)

In line with a priori expectation, increased public health expenditure is associated with decline in infant mortality in Nigeria. Increase in public health fund makes available resources that promote survival and health of children through high coverage of quality antenatal care, skilled care at birth, maternal and child postnatal care, as well as medical care for sick infants. These findings uphold the stance of extant studies such as Salahuddin et al. (2020), Kiross et al. (2020) and Nyamuranga and Shin (2019) which document public health expenditure as an important predictor of child health. Similarly, the estimation output also indicates that increasing rate of urbanization and literacy are negatively related to infant mortality in Nigeria. That is, the increase in both urbanization and literacy rate causes significant declines in the rate of infant death in Nigeria with the magnitude being higher for urbanization rate. While these lend support for the urbanization- and education-health advantages (Mensch et al., 2019; Andriano and Monden, 2019; Zhang et al., 2019; Bickler et al., 2018; Alderman and Headey; 2017; Davey et al., 2015), the estimated coefficients for urbanization is in variance with the strand of literature which argues that urbanization has deleterious effects on health (Diao et al., 2020; Hassell et al., 2017; Basta, Richmond and Wiebe, 2010, Redman and Jones, 2005)

For the neonatal mortality model, the results reported in column 3 of Table 5 show that DAH is positively related to child health in Nigeria, having a reducing effect on neonatal data. The estimated coefficient indicates that a dollar increase in DAH reduces the number of neonates dying before reaching 28 days of age by 0.08/1000 live births. In comparison with infant mortality, DAH provided by UNICEF has higher reducing effect on infant mortality than neonatal mortality. This lent support to the assertion of WHO Report (2019) in which the rate of decline in neonatal mortality is slower than infant mortality. Moreover, the obtained result might be an indication of the prevalence of high rate of births not attended by skilled health workers in Nigeria. Evidence has shown that a large proportion of neonatal death is due to conditions and diseases arising from lack of quality and skilled care at birth and in the early days of life. Although, there has been significant improvement in recent time stemming from increasing awareness campaign and various efforts of both governments and donor partners, a large number of pregnant women in Nigeria still attend antenatal meetings other than that of orthodox medicine and are delivered of their babies by uneducated and unprofessional midwives (WHO, 2019; Okereke et al., 2019; Adeoye et al. 2017). It is therefore possible that DAH has a lower relative impact on neonatal due to the prevalent high rate of unprofessional birth attendance.

For the intervening variables, as obtained under the infant mortality model, income measured by GDP growth rate has a statistically non-significant increasing effect on neonatal death in Nigeria. This finding is contrary to a priori expectation and documented evidence in support of the health is wealth hypothesis (Salahuddin et al., 2020; O'Hare et al., 2013). On the other hand, public health spending and literacy rate are correlated with reduction in the rate of neonate's

Copyright (C) 2021, Journal of Advanced Research in Economics and Administrative Sciences (JAREAS), Under a 
death. Although the effects are statistically significant, the magnitudes are quantitatively small. Compared with other intervening variables, urbanization has a quantitatively larger impact on neonatal death. Specifically, a percentage increase in degree of urbanization reduces the rate of death among neonates by $0.86 / 1,000$ live births compared with 0.001 and 0.002 respectively for public health spending and literacy rate.

Furthermore, the result presented in column IV shows that DAH provided by UNICEF significantly reduces the number of children dying before attaining age five. This affirms the conclusions of Winkleman and Adams (2016) and Bendavid and Bhattacharya (2014) which specifically investigates the influence of health target aid on under5 mortality in country specific and cross-country analyses. Moreover, with an estimated coefficient of 0.14 , the death reducing effect of DAH among children is higher for the under-5 children relative to the infants and the neonates. This stance is earlier supported by UNICEF Report (2018). Acknowledging the severity of death among children in Nigeria in spite of the recorded progress made so far, the report however establishes that improvement is highest for under-5 mortality. While infant and neonatal mortalities have declined by $26 \%$ and $20 \%$ respectively over the past two decades, death among children under age five has declined by $31 \%$.

For the impacts of DAH on children immunization coverage, we analyzed the effect of DAH provided by UNICEF on diphtheria, pertussis and tetanus (DPT) immunization and measles immunization $^{9}$, and the results are presented in column V and column VI respectively. In both cases, UNICEF-funded DAH increases the number of children age 12 - 23 months vaccinated against DPT and measles both at $1 \%$ level of significance. Immunization constitutes a crucial aspect of UNICEF programs and it is ascribed as the most cost-effective of all child health interventions. (UNICEF, 2019). According to the report, routine vaccination protects about 2 to 3 million children from diverse kinds of diseases including diarrhea, measles and pneumonia. In fact, between 2000 and 2018, measles immunization averted an estimated 23.2 million deaths among children. The obtained result might also be connected to the contributory role of national government supplemental immunization activities (SIAs). This has really supplemented the routine immunization (RI), particularly in raising awareness on the importance of RI and significantly increasing the number of children vaccinated annually. For instance, in 2019, as part of a series of SIAs, a mass vaccination campaign was launched in the 19 northern states of Nigeria and the Federal Capital Territory (Olugbade et al., 2019)

Moreover, income has an insignificant increasing effect on the number of children immunized against measles and DPT, while literacy rate and public health expenditure have reducing effects in both models. This is in variance to conclusions in empirical analyses which have identified parental education and wealth as key determinants of immunization coverage (Sarker et al., 2019; Hajizadeh, 2018; Holipah et al., 2018; Restrepos-Mendez et al., 2016).

\footnotetext{
${ }^{9}$ Both immunizations are administered for children between the ages 12 -23 months.
}

Copyright (C) 2021, Journal of Advanced Research in Economics and Administrative Sciences (JAREAS), Under a Creative Commons Attribution 4.0 International License 


\section{Conclusion and Suggestion}

This study investigated the heterogeneous effect of health aid on child health outcomes, namely, infant, neonatal and under-5 mortality rates as well as coverage for measles and DPT immunization in Nigeria. The objective was to examine whether there were gains in child health due to DAH. The study covered the period between 1970 and 2018 employing the fully modified OLS estimator. Thus, the study tested cointegration among the variables of choice and investigated the long-run relationship between the dependent variable and the main explanatory variable. It was found out that there is evidence of long-run relationship between health aid and child health outcomes. Put differently, official development assistance provided by UNICEF improved child health outcomes in Nigeria. An important policy implication emerges that efficient management of health aid inflow should be prioritized by governments at all levels for improvement in health outcomes in Nigeria.

\section{Conflict of Interest}

The authors of the article declare no conflict of interest.

\section{Funding}

This research study was not funded by any institution. The author conducted the study on his own expenses.

\section{References}

Agunbiade, O., and Mohammed, S. (2018). Impact of Foreign Aid on the Economic Development of Nigeria: 1986 - 2016. Journal of economic and sustainable development, 9(18), 69-80.

Adeoye, I., Quadri, G., and Adedini, S. (2017). Maternal health care utilization and neonatal mortality in Nigeria: looking beyond the micro-level pathway of influence. African Population Studies, 31(1). https://doi.org/10.11564/31-1-995

Alderman, H., and Headey, D. (2017). How important parental education for child nutrition? World Development, 94,448-464. https://doi.org/10.1016/j.worlddev.2017.02.007

Andriano, L. and Monden, C. (2019). The causal effect of maternal education in child mortality: evidence from a quasi-experiment in Malawi and Uganda. Demography, 56, 1765-1790. https://doi.org/10.1007/s13524-019-00812-3.

Banchani, E., and Swiss, L. (2019). The impact of foreign aid on maternal mortality, UNWIDER Working Paper No. 2019/11.

Basta, L., Richmond, T., and Wiebe, D. (2010). Neighborhoods, daily activities and measuring health risks experienced in urban environments. Soc. Sci. Med., 71(11), 1943-1950. https://doi.org/10.1016/j.socscimed.2010.09.008

Bendavid, E., and Bhattacharya, J. (2014). The relationship of health aid to population health improvements. JAMA International Medicine, 174(6), 881887.https://doi.org/10.1001/ja,aintermed.2014.292 
Bickler, S., Wang, A., Amin, S., Halbach, J., Lizardo, R., Cauvi, D., \& De Maio, A. (2018). Urbanization in sub-Saharan Africa: Declining rates of chronic and recurrent infection and their possible role in the origins of non-communicable disease. World Journal of Surgeries, 42(6), 1617-1628. https://10.1007/s00268-017-4389-5

Clarke, L., Chalkidou, K., and Nemzoff, (C). (2018). Development Impact Bonds Targeting Health Outcomes. CGD Policy Paper. Washington, DC: Center for Global Development. https://www.cgdev.org/publication/development-impact-bonds-targeting-healthoutcomes

Davey, T., Cameron, C., Ng, S., \& McClure, S. (2015). The relationship between maternal education and child health outcomes in urban Australian children in the first 12 months of life. Maternal and Child Health Journal, 19, 2501-2511. https://doi.org/10.1007/s10995-015-1771-5

Dhahri, S., Omri, A. (2020). Foreign capital towards SDGs 1 \& 2- Ending Poverty and hunger: The role of agricultural production, Structural Change and Economic Dynamics (2020), doi: https://doi.org/10.1016/j.strueco.2020.02.004

Diao, B., Ding, L., Zhang, Q., Na., J., and Cheng, J. (2020). Impact of urbanization on PM2.5related health and economic loss in China 338 cities. International Journal of Environmental Research and Public Health, 17(3), 990. https://doi.org/10.3390/ijerph17030990

Doucouliagos, C., Hennessy, J., \& Mallick, D. (2019). Health aid, governance and infant mortality. IZA Discussion Paper No. 12166.

Fashina, O., Asaleye, A., Ogunjobi, J., \& Lawal, A. (2018). Foreign aid, human capital and economic growth nexus: Evidence from Nigeria. Journal of International Studies, 11(2), 104-117. https://doi.org/10.14254/2071-8330.2018/11-2/8

Feeny, S., and De Silva, A. (2012). Measuring absorptive capacity constraints to foreign aid. Economic Modelling, 29(3), 725-733.

Furuoka, F., Hoque, M., Jacob, R., and Ziegenhain, P. (2019). An analysis of the development assistance for health (DAH) allocations for STD control in Africa. Health Economics, Policy and Law, 1-19. https://doi.org/10.1017/ S1744133119000197

Gyimah-Brempong, K., Racine, J. S., \&Gyapong, A. (2012). Aid and economic growth: Sensitivity analysis. Journal of International Development, 24(1), 17-33.

Hajizadeh, M. (2018). Socioeconomic inequalities in child vaccination in low/middle-income countries: what account for the differences? Journal of Epidemiology and Community Health, 72(8). http://dx.doi.org/10.1136/jech-2017-210296

Harb, N., and Hall, S. (2019). Does foreign aid play a role in the maintenance of economic growth?A non-linear analysis. Quarterly Review of Economics and Finance, 73, 192204.

Hassell, J., Begon, M., Ward, M., and Fevr, E. (2017). Urbanization and disease emergence: dynamics at the wildlife-livestock-human interface. Trends of ecology and Evolution, 27(1), 55-67. https://10.1016/j.tree.2016.09.012

Holipah, Maharani, A. \& Kuroda, Y. Determinants of immunization status among 12- to 23-

Copyright (C) 2021, Journal of Advanced Research in Economics and Administrative Sciences (JAREAS), Under a Creative Commons Attribution 4.0 International License 
month-old children in Indonesia (2008-2013): A. multilevel analysis. BMC Public Health 18, 288 (2018). https://doi.org/10.1186/s12889-018-5193-3

Institute for Health Metrics and Evaluation (IHME) (2019). Financing Global Health

Visualization. Seattle, WA: IHME, University of Washington 2019. Retrieved from: http://vizhub,healthdata.org/fgh/

Joseph, B., Abimiku, C., Dangiwa, D., ..., Dapar, M. (2017). Foreign aid initiatives and the HIV/AIDS epidemics in Nigeria: Perspective on country ownership and humanistic care. International STD Research and Reviews, 5(3), 1-4.

Kao, C., and Chiang, M. (2000). On the estimation and inference of a cointegrated regression in panel data. Advanced Econometrics, 15, 179e222.

Kiross, G., Chojenta, C., Barker, D., and Loxton, D. (2020). The effects of health expenditure on infant mortality in sub-Saharn Africa: evidence from panel data analysis. Health Economics Review, 10(5). https://dx.doi.org/10.1186/s13561-020-00262-3

Kosack, S. (2003). Effective aid: How democracy allows development aid to improve quality of life. World Development, 31(1), 1-22. https://doi.org/10.1016/S0305-750X(02)00177-8

Maruta, A., Banerjee, R., and Cavoli, T. (2020). Foreign aid, institutional quality andeconomic growth: Evidence from the developing world, Economic Modelling (2020), 444463.https://doi.org/10.1016/j.econmod.2019.11.008

Mahembe, E., \& Odhiambo, N. (2017). On the link between foreign aid and poverty reduction in developing countries. RevistaGalega De Economia, 26(2), 113-132.

Mahembe, E., \& Odhiambo, N. (2019). Foreign aid and poverty reduction: A review of international literature. Cogent Social Sciences, 5:1625741. https://doi.org/10.1080/23311886.2019.1625741

Mensch, B., Chuang, E., Melnikas, A., Psaki, S. (2019). Evidence for causal links between education and maternal and child health: Systematic review. Tropical Medicine and International Health, 24(5), 504-522. https://doi.org/10.1111/tmi.13218

Moyo, L., and Mafuso, L. (2017). The effectiveness of foreign aid on economic development in developing countries: A case of Zimbabwean. Journal of Social Sciences, 52(1-3), 173187. https://doi.org/10.1080/09718923.2017.1305554

Ndikumana, L., \&Pickbourn, L. (2017). The impact of foreign aid allocation on access to social services in sub-Saharan Africa: the case of water and sanitation. World Development, 90, 104-114.

Nyamuranga, C., and Shin, J. (2019). Public health expenditure and child mortality in Southern Africa. International Journal of Social Economics, 45(9), 1137-1154. https://doi.org/10/1108/IJSE-12-2018-0643

O’Hare, B., Makuta, I., Chiawaula, L., and Bar-Zeev, N. (2013). Income and child mortality in developing countries: A systematic review and meta-analysis. Journal of the Royal Society of Medicine, 106(10), 408-414. https://doi.org/10.1177/0141076813489680

Okon, E. (2012). Five decades of development aid to Nigeria: The impact on human development. Journal of Economics and Sustainable Development, 3(1), 32-42.

Okereke, E., Ishaku, S.M., Unumeri, G. et al. (2019). Reducing maternal and newborn mortality

Copyright (C) 2021, Journal of Advanced Research in Economics and Administrative Sciences (JAREAS), Under a Creative Commons Attribution 4.0 International License 
in Nigeria - a qualitative study of stakeholders' perceptions about the performance of community health workers and the introduction of community midwifery at primary healthcare level. Human Resource for Health 17, 102 (2019). https://doi.org/10.1186/s12960-019-0430-0

Olugbade, O., Adeyemi, A., Adeoti, A., ..., Aworh, M. (2019). Measles outbreaks and supplemental immunization activities: The Gwagwalada experience, Abuja 2015. Supplement 36(1). https://doi.org/10.11604/pamj.supp.2019.32.1.13368

Pedroni, P., 2000. Fully modified OLS for heterogeneous cointegrated panels. In: Baltagi, B.H., Fomby, T.B., Hill, R.C. (Eds.), Nonstationary panels, panel cointegration, and dynamic panels (Advances in Econometrics, Volume 15). Elsevier Science Inc, pp. 93e130.

Phillips, P., and Hansen, B. (1990). Statistical inference in instrumental variables regression with I(1) Processes. Review of Economic Study, 57, 99e125.

Phillips, P., and Solo, V. (1992). Asymptotics for linear processes. Annals of Statistics, 20, 9711001.

Phillips, P. (1993). Fully modified least square and vector autoregression. Cowles Foundation Discussion Paper No $1047 . \quad$ Retrieved from: https://cowles.yale.edu/sites/default/files/files/pub/d10/d1047.pdf

Phillips, P., and Moon, H. (1999). Linear regression limit theory for non-stationary panel data. Econometrica 67 (5), 1057e1111.

Pickbourn, L., \&Ndikumana, L. (2018). Does health aid reduce infant and child mortality from diarrhea in sub-Saharan Africa? The Journal of Development Studies.https://doi.org/10.1080/00220388.2018.1536264

Ramirez, M.D. (2007). A panel unit root and panel cointegration test of the complementarity hypothesis in the Mexican case: 1960-2001. Atlantic Economics. Journal, 35, 343e356.

Redman, C., and Jones, N. (2005). The environmental, social and health dimensions of urban expansion. Population and Environment, 26(6), 505, 520.

Restrepo-Mendez, M., Barros, A., Wong, K., et al. (2016). Inequalities in full immunization coverage: trends in low-and middle-income countries. Bulletin of the World Health Organization, 94, 794-805. https://dx.doi.org/10.2471/BLT.15.162172

Salahuddin, M., Vink, N., Ralph, N., \&Gow, J. (2020). Effects of economic growth, foreign direct investment and internet use on child health outcomes: empirical evidence from South Africa. Development Studies Research, 7(1), 117.https://doi.org/10.1080/21665095.2020.1717362

Sarker, A., Akram, R., Chowdhury, Z., and Sultana, M. (2019). Coverage and determinants of full immunization: Vaccination. Medicina (Kaunas) 55(8):480. https://dx.doi.org/10.3390/medicina55080480

Ssozi, J., Asongu, S., \&Amavilah, V. H. (2019). The effectiveness of development aidfor agriculture in Sub-Saharan Africa. Journal of Economic Studies, 46(2),284-305.

Tahir, M., Ruiz Estrada, M., and Afridi, M. (2019). Foreign inflows and economic growth: An empirical study of the SAARC region. Economic Systems.https://doi.org/10.1016/j.ecosys.2019.100702

Thomson, M., Kentikelenis, A., \&Stubb, T. (2017). Structural adjustment programmes adversely

Copyright (C) 2021, Journal of Advanced Research in Economics and Administrative Sciences (JAREAS), Under a Creative Commons Attribution 4.0 International License 
affect vulnerable populations: a systematic-narrative review of their effect on child and maternal health. Public Health Reviews, 38(13). https://doi.org/10.1186/s40985-0170059-2

Toseef, M., Jensen, G., and Tarraf, W. (2020). How effective is foreign aid at improving health outcomes in recipient countries. Atlantic Economic Journal,https://doi.org/10.1007/s11293-019-09645-2

Ugochukwu, S., Okafor, U., \&Akarogbe, C. (2016). Effects of external borrowing and foreign aid on economic growth in Nigeria. International Journal of Academic Research in Business and Social Sciences, 6(4), 155-175.

UNICEF (2018). Levels and trends in child mortality report. United Nations Inter-Agency Group for Child Mortality Estimation (UN-IGME) Report. Retrieved: https://www.unicef.org/publications/index_103264.html\#

UNICEF (2019). Immunization. Retrieved from: https://www.unicef.org/immunization

Wako, H, (2017). Aid, institutions and economic growth in sub-Saharan Africa: Heterogenous donors and heterogenous responses. Review of Development Economics, 22(1).https://doi.org/10.111/rode.12319

Winkleman, T., \& Adams, G. (2017). An empirical assessment of the relationship between official development aid and child mortality 2000-2015. International Journal of Public Health, 62,231-240. https://doi.org/10.1007/s00038-017-0940-2

Williamson, C. (2008). Foreign aid and human development: The impact of foreign aid to the health sector. Southern Economic Journal, 75(1), 188-207

Wilson, S, (2011). Chasing success: Health Sector aid and mortality. World Development, 39(11), 2032-2043.

World Health Organization (WHO) (2019). Newborns: reducing mortality. Retrieved: https://www.who.int/news-room/fact-sheets/detail/newborns-reducing-mortality

Yogo, U., and Mallaye, D. (2015). Health aid and health improvement in sub-Saharan Africa: Accounting for the heterogeneity between stable states and post-conflict states. Journal of International Development, 27(7), 1178-1196.

Zhang, Y., Wang, H., Wang, X., Liu. M., Wang. Y., Wang, Y and Zho, H. (2019). The association between urbanization and child height: a multilevel study in China. BMC Public Health, 19:569. https:doi.org//10.1186/s12889-019-6921-z 